\title{
Application of activated effective microorganism, mudball and biosand filter for the treatment of dye wastewater
}

\author{
Anisha Maharjan ${ }^{1, *}$, Anish Ghimire ${ }^{2}$ \\ ${ }^{1}$ Department of Environmental Science, Goldengate International College, Battisputali, Kathmandu, Nepal - 44600 \\ ${ }^{2}$ Department of Environmental Science and Engineering, School of Science, Kathmandu University, Dhulikhel, Nepal -
} 45200

(Received: 19 May 2021; Revised: 03 July 2021; Accepted: 04 July 2021)

\begin{abstract}
A study was carried out to evaluate the application of Activated Effective Microorganisms (AEM) solution and EM Mudballs (mixture of soil, rice bran, and EM) to wastewater generated from wool and cotton dyeing unit at Kumbeshwar Technical School (Lalitpur, Bagmati Province, Nepal). Furthermore, the AEM treated wastewater was treated through a Biosand filter as a final treatment and polishing step before discharge in a nearby sewerage system. The wastewater samples collected for 27 days were analyzed for the wastewater quality parameters such as $\mathrm{pH}$, Electrical Conductivity (EC), Total Solids (TS), and Chemical Oxygen Demand (COD) using the standard methods. The average values of $\mathrm{pH}$, conductivity, COD, and TS after the EM combined with Biosand (final) treatment were observed to be $7.49 \pm 1.15,1.39 \pm 0.25 \mathrm{mS} / \mathrm{cm}, 1,669.4$ $\pm 858.14 \mathrm{mg} / \mathrm{L}$, and $264 \pm 25.29 \mathrm{mg} / \mathrm{L}$, respectively. TS and COD removal were observed to be $43.97 \pm 22.3 \%$ and $15.26 \pm 10.06 \%$, respectively. The results show that the dye wastewater is difficult to remove by a simple biological process like the addition of EM. Combined EM and biosand filters can be an inexpensive way of treating industrial effluents. However, the existing treatment system needs to be optimized by the integration with the proper EM: water: molasses ratio, optimal feeding time and design, hydraulic retention time, solids retention time, organic loading rates in EM reactor, and COD/BOD ratio in wastewater among other important components to meet the national effluent discharge requirements.
\end{abstract}

Keywords: Biosand filter, dye wastewater, effective microorganism, EM mudballs

\section{Introduction}

Wastewater management has been a trending global issue due to the rapidly emerging urban areas. The problem is very much distinct, especially in developing countries such as Nepal. An estimation of $90 \%$ of wastewater in developing nations is directly discharged into the nearest water bodies, including generations from households, hospitals, agriculture, factories, and industries (Corcoran et al., 2010).

The establishment of small-scale industries like carpet, wools, pashmina and other textile industries promote the standard of living of local individuals. The textile industries use different types of chemicals for dyeing depending upon the type of clothing materials used as raw material, which are classified as cellulose (cotton, rayon, linen, ramie, hemp and lyocell), protein (wool, angora, mohair, cashmere and silk) and synthetic fibers (polyester, nylon, spandex, acetate, acrylic, ingeo and polypropylene) (Ghaly et al., 2013). A large quantity of water supply is consumed during the process of dyeing and finishing. The daily water consumption of an average-sized textile mill having the production of about $8,000 \mathrm{~kg}$ of fabric per day is about 1.6 million liters (Kant, 2012), i.e., 200 Liters/kg fabric. The dyed/pigmented waste- water contains both organic and inorganic residues and combines them in different concentrations. Discharge of dye-containing effluents into the water environment is undesirable and causes water pollutants. Many of the dyes released and breakdown products are toxic, carcinogenic, or mutagenic to life forms mainly because of carcinogens, such as Benzidine, Naphthalene, and other aromatic compounds (Saini, 2017). The effluent discharge limits for wool processing industries in Nepal recommended by the Government of Nepal are: $\mathrm{pH}$ - 5.5-9.0, Chemical Oxygen Demand (COD) - $250 \mathrm{mg} / \mathrm{l}$, Biological Oxygen Demand (BOD) - $100 \mathrm{mg} / \mathrm{l}$, and suspended solids - $100 \mathrm{mg} / \mathrm{l}$ (MoFE, 2018). The methods like floatation, coagulation, flocculation sedimentation, ozone oxidation, reverse osmosis, nanofiltration, microfiltration, aerobic biological treatment (such as activated sludge process), biological contact oxidation, photochemical oxidation, electrochemical oxidation have been used today to treat textile dyeing wastewater (Wang et al., 2011).

Textile industries, depending upon the used raw materials, can be classified into three categories viz., cotton, woolen,

\footnotetext{
* Corresponding author: anisha.green@gmail.com
} 
and synthetic fibers (Wang et al., 2011) and is one of the biggest industries in the world in terms of production and employment. As a result, it has a greater impact on the global economy (Dey \& Islam, 2015). Dyeing is a complicated process that consists of dyeing and washing the textile. This requires the consumption of a large quantity of surface and groundwater. The water consumption rate for dyeing varies from 30 - 50 liters per $\mathrm{kg}$ of cloth, depending upon the type of dye used (Kant, 2012). The overall water consumption of yarn dyeing is about 60 liters per $\mathrm{kg}$ of yarn, and about 10\%-15\% of the total dye used in the dyeing process is lost as the effluent (Al-Ghouti et al., 2003). This results in both physical and chemical pollution of the much greater volume of water on both surface and underground by direct or indirect mixing of effluents in these bodies. The pollution caused by these pigments is intense because the chemical dyes used today are basic and reactive. They are bright-colored, water-soluble, cheaper to produce, easy to apply on textile materials, and do not easily fade away to extensive heat, light and water (Karadag et al., 2007).

Due to the introduction of various chemical pigments, changes in the characteristics of water occurs. $\mathrm{pH}$, color, Biological Oxygen Demand (BOD), Chemical Oxygen Demand (COD), Total Dissolved Solids (TDS), Total Suspended Solids (TSS), Total Solids (TS), Electrical Conductivity (EC), and turbidity tend to show the varying values due to the use of large quantities of textile dyes (Zaharia et al., 2009).

Although chemical dyes are beneficiary for the textile industries, it is antithetic for the natural environment. The effect of the effluents in the water bodies can be long-termed or short-term, depending upon the dye type and its concentration. More is the exposure to the environment more is its footprint. These dyes have chromatic characteristics. This causes turbidity in water bodies and reflects sunlight penetrating inside (Slokar \& Majcen Le Marechal, 1998). Light absorption diminishes the photosynthesis activity of algae causing oxygen deficiency resulting in disturbances in the whole aquatic ecosystem and also affect the property of water to cleanse itself. It also limits downstream beneficial uses such as recreation, drinking water, and irrigation. Moreover, chemical dyes have replaced natural dyes because they are resistant to heat, light, and water. They are basic and reactive, thus quickly absorb dyes, and are also cheaper, water-soluble, bright-colored, and easy to apply to the fabrics (Vigneshpriya \& Shanthi, 2015). Many dyes and their breakdown products are carcinogenic, mutagenic, and toxic to life (Kant, 2012). Entrance in the body by ingestion is metabolized by intestinal microorganisms causing DNA damage. The traces of heavy metals and colored effluents cause corrosion in the pipelines; this also affects the productivity of land and soil and produces stench, which further causes air pollution (Kant, 2012).
Effective Microorganisms (EM) is a constituent of environmentally abundant aerobic and anaerobic microorganisms like lactic acid bacteria, photosynthetic bacteria, fungi, and fewer amounts of actinomycetes that comes in a dark brown color which is environment friendly (Suthar et al., 2017). EM is not genetically engineered (non-genetic modification organism), not pathogenic, not harmful, and not chemically synthesized (Zakaria et al., 2010). EM has found its application in various fields that include agriculture, nourishing soil, composting, gardening, sludge reduction, removal of putrefied smell and odor, restoration of water bodies, and other environmental areas (Fan et al., 2018; Shaheen et al., 2017; Sitarek et al., 2017; Talaat, 2019).

In the case of wastewater treatment, EM works by breaking down the organic matter. They are decomposed and converted into carbon dioxide $\left(\mathrm{CO}_{2}\right)$, methane $\left(\mathrm{CH}_{4}\right)$, or get used up when individual microorganisms multiply synergistically when exposed to an anaerobic environment, reducing the unwanted by-products and residues; the species used in the EM contain organic acids secrete antioxidants along with the metallic chelate and enzymes, and these antioxidants are responsible for the enhancement of solid-liquid separation in wastewater (Namsivayam et al., 2011; Szymanski et al., 2003; Zakaria et al., 2010). This makes EM an attractive option to be used in wastewater treatment for the removal of conventional pollutants like COD and BOD.

The Biosand filter is a point-of-use (POU) treatment technology mostly used in drinking water treatment. It consists of sand particles, small and big gravels that treat the wastewater. Biofilm is a thin sticky layer produced by microorganisms that colonize the sand (Fiore et al., 2010). The purpose of this biofilm is to trap the pathogens in the wastewater. Biosand filter removes pathogens by means of biological, physical, and mechanical processes (Ibrahim, 2009). It is similar to a sand filter where filtration and turbidity are removed from the upper layer of the sand bed itself due to its smaller pore size (Yung, 2003).

This work aims to evaluate the effectiveness of Activated Effective Microorganisms (AEM) solution and EM Mudballs for wastewater generated from wool and cotton dyeing unit at Kumbeshwar Technical School located at Lalitpur, Bagmati Province, Nepal. EM in the market is available in the quiescent state, which requires activation; hence, EM and chlorine-free water is mixed in the ratio of 1:20 with $2 \mathrm{~kg}$ of jaggery to active the microorganisms; it takes about a week to complete the fermentation forming a white layer of actinomycetes (Namasivayam \& Bharani, 2012). The dye wastewater generated is treated by a biological reactor which offers favorable conditions to apply AEM and EM mudballs and subsequent final treatment by Biosand filter. The study evaluates the performance of these individual treatment units by evaluating the physicochemical characters of wastewater treated by AEM and biosand filter.

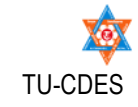


Nep J Environ Sci (2021), 9(1), 41-48

https://doi.org/10.3126/njes.v9i1.37376

\section{Materials and methods}

\section{Study Area}

Kumbeshwar Technical School (KTS) is located in the geographic coordinates of $27.68^{\circ} \mathrm{N}, 85.33^{\circ} \mathrm{E}$ and is located in Kumbeshwar -22, Lalitpur district. It is an educational and vocational training center supporting the needs of low-income families throughout Nepal. KTS was initially established to assist locals of the community who were termed untouchables and were denied education and employment opportunities. In 1987 A.D., KTS opened a primary school where carpet weaving training programs were conducted, and a production unit was established to fund the school. Local children from low-income families learn literacy skills and receive education at the Nursery and Primary levels. KTS also runs vocational training in carpet weaving, hand knitting, and carpentry.

Wastewater Treatment using EM and Biosand Filter

Dye Wastewater Treatment Scheme at KTS is shown in Figure

1. The wastewater is treated biologically in tanks with EM and subsequent treatment by Biosand filter. EM used in the study area is manufactured and supplied by a private company, Niva Rain, Kathmandu, Nepal. They are of two types; one is a dark brown color with a $\mathrm{pH}$ value of 7.6, and the other is a mudball that weighs approximately 300 grams per ball. It is applied in an underground storage tank that is supplied with cooled dyed wastewater with a capacity of 2,000 liters. The underground storage is fed daily with 2 liters of EM solution. This implies that 1 liter of EM solution is applied for 1,000 liters of wastewater (1: 1,000). Four EM mudballs are fed in the same tank once every month. The effluent from the biological step is further transferred to a 500 liters' overhead tank, which contains 6EM mudballs at the rate of $2 \mathrm{~L} / \mathrm{min}$. These EM mudballs are fed in the tank once a month. Finally, the EMtreated wastewater is passed down to the Biosand filter before discharging to the sewerage, which has the capacity of filtering $2 \mathrm{~L} / \mathrm{min}$.

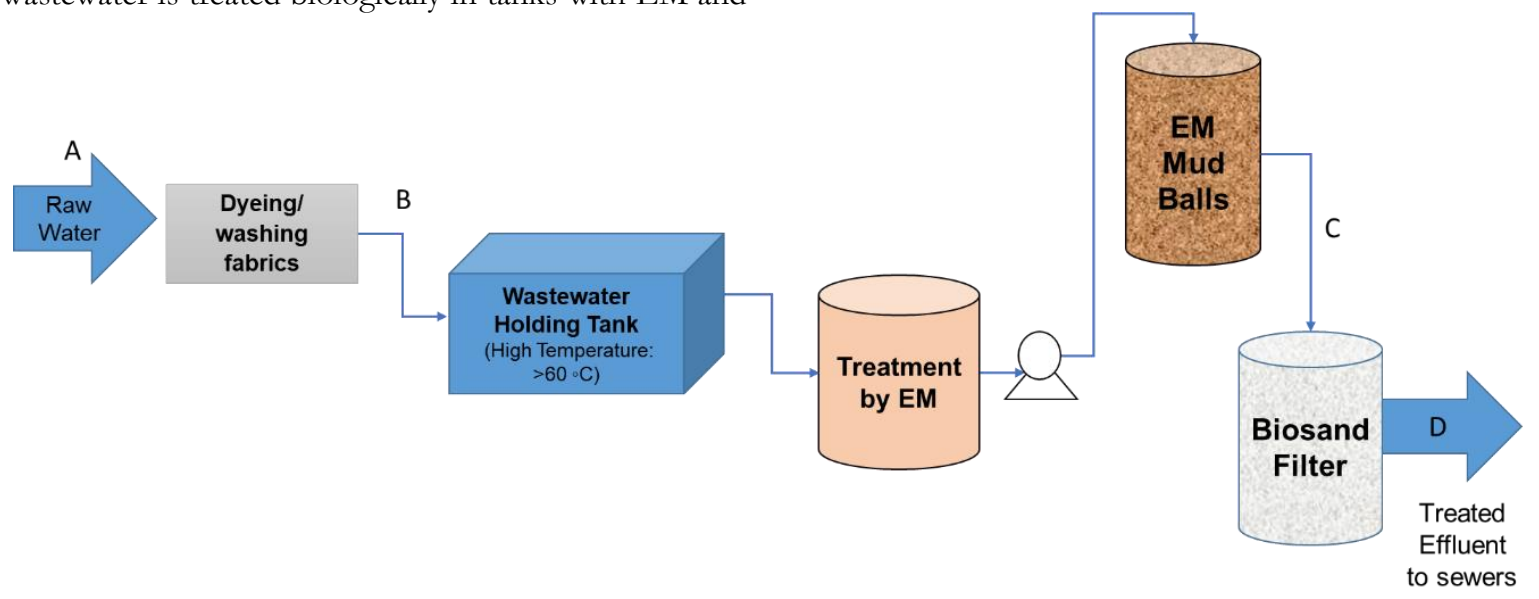

Figure 1 Dye Wastewater Treatment Scheme at KTS

\section{Sample Collection}

Samples were collected for 27 days from February 13 to March 11, 2018; four different samples of effluents were collected from the individual treatment units. The samples taken were raw water (A) that was used for dyeing. Raw water is supplied from a private water supply facility, Shree Ujjwal Suppliers, Jorpati, Kathmandu. Other samples were dyed effluent (B), EM solution and EM mudball treated effluents (C), and biosand filtered effluents (D). These samples were collected in glass bottles.

\section{Physicochemical Characterization of Dye Effluents}

Four different physicochemical parameters, including $\mathrm{pH}$, Electrical Conductivity (EC), color, Total Solids (TS), and Chemical Oxygen Demand (COD), were determined following the standard protocols (APHA, 2005). These parameters were analyzed for samples collected from the different points of the wastewater treatment plant.

\section{Results and Discussion}

The treated wastewater is colored, acquired objectionable odor, slightly alkaline $\mathrm{pH}$, high TS, moderate COD, and low $\mathrm{pH}$, which showed the treatment was ineffective. The analytical results for $\mathrm{pH}, \mathrm{EC}, \mathrm{TS}$, and COD of dye wastewater, EM treated, and biosand treated wastewater used for dyeing and washing woolen and cotton textile in the study site are tabulated in Table 1.

The average $\mathrm{pH}$ value of sampled days for raw water was observed to 6.93. According to National Drinking Water Quality Standards (NDWQS, 2005), the value for $\mathrm{pH}$ is within the standards. The average value of $\mathrm{pH}$ for dye, EM treated, and biosand treated wastewater was noted to be 6.64 \pm 0.64 , $7.16 \pm 1.01$, and $7.49 \pm 1.15$, respectively. 
Nep J Environ Sci (2021), 9(1), 41-48

https://doi.org/10.3126/njes.v9i1.37376

Table 1 Characteristics of wastewater effluents sampled at various points

\begin{tabular}{llccc}
\hline Wastewater Type & $\mathrm{pH}$ & $\begin{array}{c}\mathrm{EC} \\
(\mathrm{mS} / \mathrm{cm})\end{array}$ & $\mathrm{TS}(\mathrm{mg} / \mathrm{L})$ & $\mathrm{COD}(\mathrm{mg} / \mathrm{L})$ \\
\hline Dye wastewater $(\mathrm{B})$ & $6.64 \pm 0.64$ & $2.41 \pm 0.91$ & $3058.33 \pm 1052.91$ & $313.33 \pm 26.9$ \\
EM treated (C) & $7.16 \pm 1.01$ & $1.67 \pm 1.14$ & $2259.72 \pm 917.14$ & $304 \pm 25.3$ \\
Biosand Treated (D) & $7.49 \pm 1.15$ & $1.39 \pm 0.25$ & $1669.4 \pm 858.14$ & $264 \pm 25.29$ \\
\hline
\end{tabular}

While the $\mathrm{pH}$ value of dye water exhibited a marginally acidic nature, the application of EM and biosand further reduced its value only slightly. According to Federal Environmental Protection Agency (FEPA), the recommended $\mathrm{pH}$ value for industrial effluents ranges between 6-9. The fluctuating value has different impacts on the biological activities of living organisms if discharged without adjusting its value. Some can thrive in low $\mathrm{pH}$ soil and water, while others require high $\mathrm{pH}$ for survival (Vigneshpriya \& Shanthi, 2015).

The average values for conductivity were observed to be 0.29 $\mathrm{mS} / \mathrm{cm}$ for raw water while the values were observed to be $2.41 \pm 0.91 \mathrm{mS} / \mathrm{cm}, 1.67 \pm 1.14 \mathrm{mS} / \mathrm{cm}$, and $1.39 \pm 0.25 \mathrm{mS} / \mathrm{cm}$, respectively for dye, EM treated, and biosand treated, which were very less (Table 1). The value of EC was in decreasing trend from dye water to EM treated till the final biosand treated water.
Conductivity, the capacity of water to conduct electricity, is directly related to TDS (Dey \& Islam, 2015). The value of EC was in decreasing trend from dye water to EM treated till the final biosand treated water. This indicates that inorganic dissolved solids were removed during the treatment process. The values demonstrated the similar conductivity character of dye effluent in Bangladesh. The average value of untreated dye water was found to be $4.7 \mathrm{mS} / \mathrm{cm}$, and that of treated was $0.98 \mathrm{mS} / \mathrm{cm}$ (Islam \& Mostafa, 2020), showing a similar range of conductivity in dye wastewater.

The values of total solids in dye water were $3058.33 \pm 1052.91$ $\mathrm{mg} / \mathrm{L}$ which decreased to $2259.72 \pm 971.1 \mathrm{mg} / \mathrm{L}$, and then $1669.4 \pm 858.14 \mathrm{mg} / \mathrm{L}$ in EM treated, and biosand filtered wastewater, respectively and has an average removal percentage of $43.97 \pm 22.3 \%$ (Table 2 ).

Table 2 Removal percentage of TS and COD

\begin{tabular}{lllllll}
\hline & Initial (dyewater) & $\begin{array}{l}\text { EM treated } \\
\text { water }\end{array}$ & $\begin{array}{l}\text { Final (Biosand } \\
\text { filter })\end{array}$ & $\begin{array}{l}\text { Removal } \\
(\%) \text { Dye \& } \\
\text { EM }\end{array}$ & $\begin{array}{l}\text { Removal } \\
(\%) \text { EM \& } \\
\text { Biosand }\end{array}$ & $\begin{array}{l}\text { Removal } \\
(\%) \text { Dye \& } \\
\text { Biosand }\end{array}$ \\
\hline TS & $3058.33 \pm 1052.91$ & $2259.7 \pm 971.1$ & $1669.4 \pm 858.14$ & $24.89 \pm 20.20$ & $24.23 \pm 28.83$ & $43.97 \pm 22.3$ \\
COD $313.33 \pm 26.9$ & $304 \pm 25.3$ & $264 \pm 25.29$ & $2.79 \pm 5.89$ & $12.9 \pm 8.19$ & $15.26 \pm 10.06$ \\
\hline
\end{tabular}

The results from the analysis indicate that there was a decrease of total solid by $43 \%$ after the final treatment. This means that the treatment process could reduce the concentration of both dissolved and suspended solids by half. In some cases, the TS of biosand filtered water was higher than that of the EMtreated water. This is because the concentration of dye deposited on the upper lid and biofilm of biosand filter is washed away along with EM-treated water. The TS decreases the pathway for light penetration in water, slowing photosynthesis and further heats up the water. This results in the disturbance in an aquatic habitat that is adapted to a lower temperature regime. The average COD value for dye wastewater was $313.33 \pm 26.9 \mathrm{mg} / \mathrm{L} ; 304 \pm 25.3 \mathrm{mg} / \mathrm{L}$ and $264 \pm 25.29 \mathrm{mg} / \mathrm{L}$ for EM treated and biosand wastewater, respectively (Table 2 ).
The limit concentration of COD has different values for different countries. For Nepal, China, the US, Germany, India, Pakistan, and Bangladesh, the reported COD concentration are $280-360 \mathrm{mg} / \mathrm{L}, 100 \mathrm{mg} / \mathrm{L}, 160 \mathrm{mg} / \mathrm{L}, 163 \mathrm{mg} / \mathrm{L}, 156-400$ $\mathrm{mg} / \mathrm{L}, 150 \mathrm{mg} / \mathrm{L}$, and $200 \mathrm{mg} / \mathrm{L}$, respectively (Dey \& Islam, 2015; Wang et al., 2011) whereas, COD value limit for wool processing industry is $250 \mathrm{mg} / \mathrm{L}$ as stated by the Environmental Protection Act - 2054, Government of Nepal.

A comparative study is important to understand the status of the dye wastewater of Nepal. Hence, the comparison of the COD value of Nepal with other countries is given based on the literature in Table 2 below. It can be observed that COD is highest in Pakistan (3206 mg/L) (Liang et al., 2018) and lowest in Nepal (313.33 mg/L) based on the literature available. From data, it is clear that dye wastewater in this study is 
Nep J Environ Sci (2021), 9(1), 41-48

https://doi.org/10.3126/njes.v9i1.37376

moderate to less polluted than in other countries. However, it

$250 \mathrm{mg} / \mathrm{L}$.

still ranges above the standard textile effluents of Nepal, i.e.,

Table 3 A comparison of reported COD values of textile wastewater in China, India, Pakistan, Bangladesh, and Nepal

\begin{tabular}{lccccc}
\hline Parameter & China* & India** & Pakistan*** & Bangladesh**** & Nepal***** \\
COD $(\mathrm{mg} / \mathrm{L})$ & 2200 & 638.5 & 3206 & 2120 & 313.33 \\
\hline \multicolumn{2}{c}{ (Sources: ${ }^{* * *}$ Abbasi et al., 2021; **Kaur \& Kainth, 2020; ****Rabbi et al., 2018; *Yang et al., 2019; ***** present study) }
\end{tabular}

The average COD removal percentage was $15.26 \pm 10.06 \%$ (Table 2), which is lower than the efficiency of conventional treatment plants like activated sludge and constructed wetlands (80-90\%). A study on EM bacteria (yeast) for high oil-containing wastewater indicated COD removal of more than 94\% (Qadir, 2019). The use of EM with sediment aeration for the treatment of aquaculture lake in Baima Lake, Jiangsu, China resulted in the COD value plunging from 14.6 $\mathrm{mg} / \mathrm{L}$ to $6.2 \mathrm{mg} / \mathrm{L}$ over seven months (from hypereutrophic to light eutrophic); the controlled lake without the bioremediation witnessed the COD increment from 41.2 $\mathrm{mg} / \mathrm{L}$ to $20.9 \mathrm{mg} / \mathrm{L}$ (Wang et al., 2019).

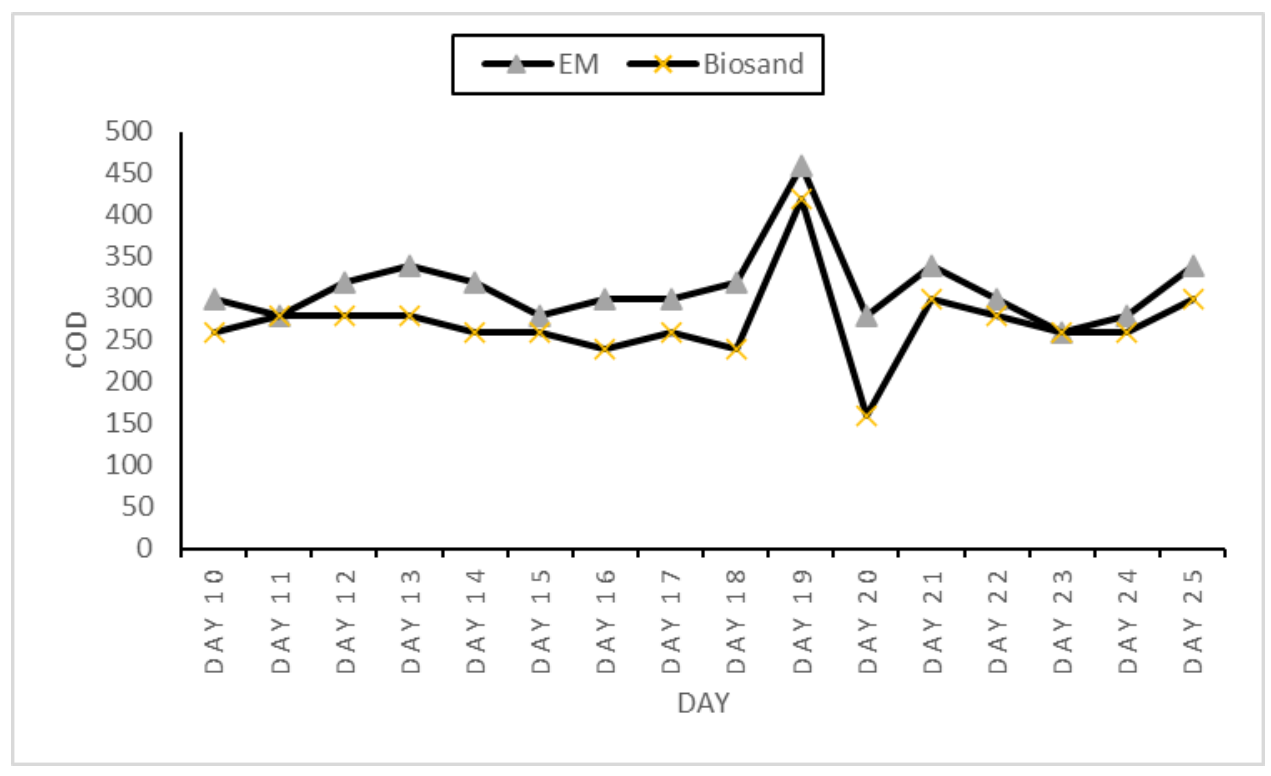

Figure 2 Comparisons of wastewater on different days in terms of COD

In this study, although COD in the treated effluent was reduced close to the upper concentration limit of Nepal (250 $\mathrm{mg} / \mathrm{L}$ ), the removal percentage was not very convincing $(15.26 \pm 10.06 \%)$. While the earlier studies used the combination of chemical flocculation, activates carbon, and aeration units, the treatment system in this study had a simple storage tank for EM treatment followed by the biosand filter. The aeration provides oxygen for bacteria for treating and stabilizing the wastewater; bacteria use oxygen to break down organic matter containing carbon to give carbon dioxide and water (Byrne, 2018). While treating domestic wastewater in a reactor filled with polyurethane foam by adding EM, it was found that the COD removal rate was $67.8 \%$ after four months of study under a hydraulic loading of $76.4 \mathrm{~mm} / \mathrm{d}$; after EM was introduced in the column, the average elimination was more than 60\% (Chmielowski et al., 2020). This lower COD removal rate was possibly due to the presence of an organic compound, which could not be degraded easily, but an anoxic environment was created within the column with which the bacteria performed better at orthophosphate removal.

Certainly, EM tends to increase the biological diversity of microorganisms and decomposition of organic matter, improve the nitrogen fixation cycle, enhances nutrient uptakes by plants, enhances the soil quality, and yield crop productivity (Joshi et al., 2019). EM application alleviates salinity problems by regulating both mechanisms of photosynthetic apparatus; hence, it could be used to improve the harmful effects of salt stress and could be explored in agricultural production as well 
(Talaat, 2019). As there are proven studies in agriculture and organic waste, the research can focus on this theme and help lessen the dependency on chemical fertilizers. This study suggests that the applications of EM or EM mud balls enhance the biological wastewater treatment processes; however, proper operations conditions need to be maintained to get the optimal performance. Additionally, conditions such the poor nutrient availability (carbon: nitrogen: phosphorous ratio) in dye wastewater and biodegradability of the effluent could be the limiting factor for the poor biological removal of the COD in this study. The ratio of EM to wastewater also determines its working efficiency. The addition of 1:1000 EM treatment showed higher COD removal than that of 1:50,000 (20\%-50\%) under aerobic conditions incubated for 6-8 days (Liao et al., 2008). Although the EM ratio was 1:1000 for our study, the COD removal was very low. This indicates that COD removal can be enhanced by either adopting intermittent aeration and followed by sedimentation (i.e., of Sequencing Batch Reactor) in the EM dosing tanks to enhance the growth and metabolism of aerobic microorganisms or increasing solid retention time (SRT) or hydraulic retention time (HRT) which provide sufficient incubation periods for anaerobic microorganisms. These two may help to provide more favorable conditions for the microorganism population. In contrast, the present operating conditions of the treatment system under the study have contradicted as the calculated HRT was 16 hours which may not be sufficient for the anaerobic microorganisms. This is certainly due to improper design and the lack of proper operational know-how of these treatment units. It is also important to note that, according to the existing literatures, use of activated EM and EM mudballs augment biological treatment in wastewater, however, it cannot be used as the sole component. It can be a method of cost effective and organic intervention when integrated with the proper EM:water:molasses ratio, optimal feeding time and design, COD/BOD ratio in wastewater among other components. More research is needed to ascertain the effect of these parameters in the biological treatment of industrial effluents like dye wastewater.

\section{Conclusion}

The study was undertaken to evaluate the application of AEM, $\mathrm{EM}$, and Biosand filtration in treating textile dye wastewater. The existing treatment system using EM technology could reduce the solids, but there was no appreciable reduction in COD value. The application of EM, EM Mudballs, and Biosand filtration in the existing conditions could not bring the effluent to the discharge limits prescribed by the government of Nepal. Therefore, the existing treatment plant needs optimization for operating conditions to enhance the biological activities of microorganisms. Likewise, the effectiveness of the biological treatment for industrial effluent, like dye wastewater, needs to be investigated further.

Acknowledgements: The authors would like to appreciate the support from the Department of Environment Science,
Goldengate International College, Kathmandu, and Kumbeshwar Technical School, Lalitpur.

Author Contributions: AM: Conceptualization, sampling and laboratory analysis, and drafting the original manuscript; AG: Supervision, formal analysis, writing, reviewing and editing.

Conflict of Interest: The authors declare no conflict of interest.

\section{References}

Abbasi, I.A., Soomro, A.F., Abbasi, S.A., Abbasi, N.A., Baig, Z.T., \& Junejo, A. (2021). The effect of mixed liquor volatile suspended solids and hydraulic retention time on the removal efficiency of chemical oxygen demand through aerobic. International Journal on Emerging Technologies, 12(2), $54-59$.

Al-Ghouti, M.A., Khraisheh, M.A.M., Allen, S.J., \& Ahmad, M.N. (2003). The removal of dyes from textile wastewater: A study of the physical characteristics and adsorption mechanisms of diatomaceous earth. Journal of Environmental Management, 69(3), 229-238. doi 10.1016/j.jenvman.2003.09 .005 .

APHA. (2005). Standard methods for the examination of water and wastewater. 21st Edition, American Public Health Association/American Water Works Association/ Water Environment Federation, Washington DC.

Byrne, W. (2018). Why is aeration important for wastewater treatment? Oxymem, retrieved January 18, 2021 from http:/ /info.oxymem.com/blog/why-is-aeration-importantfor-wastewater-treatment.

Chmielowski, K., Pawełek, J., \& Dacewicz, E. (2020). Treatment of high strength domestic sewage on filters filled with polyurethane foam with addition of effective microorganisms. Archives of Environmental Protection, 46(1), 21-32. doi 10.24425/aep.2020.132522.

Corcoran, J., Winter, M.J., \& Tyler, C.R. (2010). Pharmaceuticals in the aquatic environment: A critical review of the evidence for health effects in fish. Critical Reviews in Toxicology, 40(4), 287-304. doi 10.3109/104084409 03373590.

Dey, S., \& Islam, A. (2015). A review on textile wastewater characterization in Bangladesh. Resources and Environment, 5(1), 15-44. doi 10.5923/j.re.20150501.03.s.

Fan, Y. Van, Lee, C.T., Klemeš, J.J., Chua, L.S., Sarmidi, M.R., \& Leow, C.W. (2018). Evaluation of Effective Microorganisms on home scale organic waste composting. Journal of Environmental Management, 216, 41-48. doi 10.1016/ j.jenvman.2017.04.019.

Fiore, M.M., Minningts, K., \& Fiore, L.D. (2010). Assessment of biosand filter performance in rural communities in southern coastal Nicaragua: an evaluation of 199 households. Rural and Remote Health, 10(3), 1483. doi 10.226 05/RRH1483.

Ghaly, A., Ananthashankar, R., Alhattab, M., \& Ramakrishnan, V. (2013). Production, characterization and 
Nep J Environ Sci (2021), 9(1), 41-48

https://doi.org/10.3126/njes.v9i1.37376

treatment of textile effluents: A critical review. Journal of Chemical Engineering \& Process Tecbnology, 05(01). doi 10.4172/ 2157-7048.1000182.

Ibrahim, M.B. (2009). Rainwater harvesting for urban areas : a success story from Gadarif City in Central Sudan. Water Resources Management, 23(13), 2727-2736. doi 10.1007/s1126 9-009-9405-6.

Islam, M.R., \& Mostafa, M.G. (2020). Characterization of textile dyeing effluent and its treatment using polyaluminum chloride. Applied Water Science, 10(5), 1-10. doi 10.1007/s132 01-020-01204-4.

Joshi, H., Choudhary, P., \& Mundra, S.L. (2019). Role of effective microorganisms (EM) in sustainable agriculture. International Journal of Current Microbiology and Applied Sciences, 8(3), 172-181. doi 10.20546/ijcmas.2019.803.024.

Kant, R. (2012). Textile dyeing industry an environmental hazard. Natural Science, 4(1), 22-26. doi 10.4236/ns.2012.410 04.

Karadag, D., Akgul, E., Tok, S., Erturk, F., Kaya, M.A., \& Turan, M. (2007). Basic and reactive dye removal using natural and modified zeolites. Journal of Chemical \& Engineering Data, 52(6), 2436-2441.

Kaur, H., \& Kainth, G.S. (2020). Physiochemical assessment of Ludhiana Textile Industry effluent near Buddha Nullah. International Journal of Advance Study and Research Work, 3(3), 15-20. doi 10.5281/zenodo.3732462.

Liang, J., Ning, X., Sun, J., Song, J., Lu, J., Cai, H., \& Hong, Y. (2018). Ecotoxicology and environmental safety toxicity evaluation of textile dyeing effluent and its possible relationship with chemical oxygen demand. Ecotoxicology and Environmental Safety, 166, 56-62. doi 10.1016/j.ecoenv.2018 .08 .106 .

Liao, L., Shao, X., Xu, J.Z., \& Walter, M. (2008). Effects of different EM solution addition ratios and incubation methods on dairy effluents treatment. 2nd International Conference on Bioinformatics and Biomedical Engineering, ICBBE 2008, 5, 3466-3468. doi 10.1109/ICBBE.2008.370.

MoFE. (2018). Collection of environmental standards and related information. Kathmandu: Ministry of Forest and Environment (MoFE), Government of Nepal.

Namasivayam, S.K.R., \& Bharani, R.S.A. (2012). Effect of compost derived from decomposed fruit wastes by effective microorganism (EM) technology on plant growth parameters of Vignamungo. Journal of Bioremediation \& Biodegradation, 03(11). doi 10.4172/2155-6199.1000167.

Namsivayam, S.K.R., Narendrakumar, G., \& Kumar, J.A. (2011). Evaluation of effective microorganism (EM) for treatment of domestic sewage. Journal of Experimental Sciences, 2(7), 30-32.

NDWQS. (2005). National drinking water quality standards, 2005, and implementation directives for national drinking water quality standards, 2005. Ministry of Physical Planning and Works, Government of Nepal.

Qadir, G. (2019). Yeast a magical microorganism in the wastewater treatment. Journal of Pharmacognosy and Phytochemistry, 8(4), 1498-1500.
Rabbi, M.A., Hossen, J., Sarwar, M., Roy, P.K., Shaheed, S.B., \& Hasan, M.M. (2018). Investigation of wastewater quality parameters discharged from textile manufacturing industries of Bangladesh. Current World Environment, 13(2), 206-214.

Saini, R.D. (2017). Textile organic dyes: polluting effects and elimination methods from textile wastewater. International Journal of Chemical Engineering Research, 9(1), 975-6442.

Shaheen, S., Khan, M., Khan, M.J., Jilani, S., Bibi, Z., Munir, M., \& Kiran, M. (2017). Effective microorganisms (EM) coapplied with organic wastes and NPK stimulate the growth, yield and quality of spinach (Spinacia oleracea L.). Sarbad Journal of Agriculture, 33(1), 30-41. doi 10.17582/journal.sja/ 2017.33.1.30.41.

Sitarek, M., Napiórkowska-Krzebietke, A., Mazur, R., Czarnecki, B., Pyka, J.P., Stawecki, K., Olech, M., Sołtysiak, S., \& Kapusta, A. (2017). Application of effective microorganisms technology as a lake restoration tool a case study of muchawka reservoir. Journal of Elementology, 22(2), 529-543. doi 10.5601/jelem.2016.21.2.1196.

Slokar, Y.M., \& Majcen Le Marechal, A. (1998). Methods of decoloration of textile wastewaters. Dyes and Pigments, 37(4), 335-356. doi 10.1016/S0143-7208(97)00075-2.

Suthar, H., Hingurao, K., Vaghashiya, J., \& Parmar, J. (2017). Fermentation: A process for biofertilizer production. In Microorganisms for Green Revolution (pp. 229-252). doi 10.1007 /978-981-10-6241-4_12.

Szymanski, N., Patterson, R.A., Wagga, W., Council, C., \& Laboratories, L. (2003). Effective microorganisms (EM) and wastewater systems. In Patterson, R.A.\& Jones M.J. (Eds.), Future Directions for On-Site Systems: Best Management Practice Proceedings of On-site '03 Conference, (pp. 347-354). University of New England, Armidale.

Talaat, N.B. (2019). Effective microorganisms: an innovative tool for inducing common bean (Phaseolus vulgaris L.) salttolerance by regulating photosynthetic rate and endogenous phytohormones production. Scientia Horticulturae, 250, 254265. doi 10.1016/j.scienta.2019.02.052.

Vigneshpriya, D., \& Shanthi, E. (2015). Physicochemical characterization of textile wastewater. International Journal of Innovative Research \& Development, 4(10), 48-51.

Wang, L., Shao, X., Xu, M., \& Chen, S. (2019). Bioremediation of nitrogen- and phosphorus-polluted aquaculture sediment by utilizing combined immobilized effective microorganisms and sediment aeration technology. International Journal of Agricultural and Biological Engineering, 12(6), 192-201. doi 10.25165/j.ijabe.20191206.4904.

Wang, Z., Xue, M., Huang, K., \& Liu, Z. (2011). Textile dyeing wastewater treatment. In Hauser, P.J. (Ed.), Advances in Treating Textile Effluent, North Caroline State University, USA.

Yang, L., Qian, Y., \& Zhou, X. (2019). Current status of textile industry wastewater treatment in China: A mini review. Minimisation of Wastewater Emissions from Textile Finishing Industries (pp. 23-30)., Stuttgart, Germany.

Yung, K. (2003). Biosand Filtration: Application in the developing world. Project \# CE 401, Civil Engineering Department, 
Nep J Environ Sci (2021), 9(1), 41-48

https://doi.org/10.3126/njes.v9i1.37376

University of Waterloo.

Zaharia, C., Suteu, D., Muresan, A., Muresan, R., \& Popescu, A. (2009). Textile wastewater treatment by homogeneous oxidation with hydrogen peroxide. Environmental Engineering and Management Journal, 8(6), 1359-1369. doi 10.30638/eemj .2009 .199 .
Zakaria, Z, Gairola, S., \& Shariff, N.M. (2010). Effective microorganisms (EM) technology for water quality restoration and potential for sustainable water resources and management. Modelling for Environment's Sake: Proceedings of the 5th Biennial Conference of the International Environmental Modelling and Software Society, IEMSs 1, 80-87. 